\author{
Aneta Dawidowicz \\ Department of Political Sciences \\ Maria Curie-Skłodowska University (Lublin)
}

\title{
A Vision of the State's Political System in the Political Thought of the National Party between 1928 and $1939^{1}$
}

\begin{abstract}
Views of the National Party (1928-1939) merit special attention, given both the Party's prominent role in the political life of interwar Poland and the interesting combination of various elements derived from diverse ideological trends within the Party's programme. The ideological legacy of the National Party reflected, to a large extent, the key constituents of the National Democracy's political thought, such as nationalism, representation of all social classes, national integrity and the concept of the nation-state. The National Party underwent major evolution and was subject to internal divisions which makes the image of its political thought much more complex. Based on an analysis of the National Party's political thought, several conclusions can be formulated. The National Party developed its own views regarding political systems. These were, to a large extent, determined by their own system of values based on the national idea. The National Party's political system projections were mainly inspired by (1) the successes of the "new type" states; (2) pressure from totalitarian systems; and (3) the influence of the economic and spiritual crisis. The National Party leaders wanted to make the political system more efficient. Nonetheless, views in favor of directly imitating any foreign political systems could hardly be found in the Party's political thought. The National Party's ideologists and journalists invariably stated that there was no pre-defined political system, but its form had to be adjusted to the specificity and unique character of a given national body. Although inspiration was drawn from external political systems, the Party's political thought did not lose its independence.
\end{abstract}

Keywords: political thought, National Party, nationalism, political system

1 This article was drawn up within the framework of the research project entitled "The National Party's Political Thought in 1928-1939," financed from the resources granted by the National Science Centre under decision No. DEC-2013/09/B/HS5/00016. 


\section{Introductory Remarks}

Views of the National Party (1928-1939) merit special attention, given both the Party's prominent role in the political life of interwar Poland, and the interesting combination of various elements derived from diverse ideological trends within the Party's programme. The ideological legacy of the National Party reflected, to a large extent, the key constituents of the National Democracy's political thought, such as nationalism, representation of all social classes, national integrity and the concept of the nation-state. The National Party underwent major evolution and was subject to internal divisions which makes the image of its political thought much more complex.

The National Party's ideological contribution to Nationalist political thought and, broadly speaking, to Polish and European political thought, was significant. The National Party's political thought covered a wide range of ideological, political, systemic, historiosophical, philosophical, pedagogical, social, and economic issues. Its creators developed a vision of multiple categories referring, inter alia, to the nation, the state, political power, the economy, society, national education, the attitude to Catholicism, the status of national minorities and foreign policy as well as external and internal security.

The National Party's political thought was determined by diverse ideological, political, social and economic factors. The most significant ones included (1) the authoritarian state model implemented by the pro-Piłsudski formation; (2) the development of anti-democratic and anti-parliamentary tendencies in Europe; (3) the development of totalitarian movements within many European countries; (4) the growing political and military potential of Germany; and (5) the huge economic crisis and its numerous social implications.

The principal objective of this article is to present selected elements of the National Party's views on the state's political system in the context of political science. Other objectives include outlining the ideological, conceptual and programme-related image of the National Party, along with the factors determining its ideas, concepts, and views, regarding the state's political system.

An analysis of the previous studies on this subject-matter has revealed that the scientific reflection on Polish nationalism is still incomplete, and calls for extensive verification. The subject matter dealt with in this article has filled in a major research gap.

Induction was the underlying research method employed by the author. Among the research techniques used in the study, the analysis of various proofs and traces of political thought became the most prevalent. Other research methods which proved useful in implementing the research objectives included the systematization of political concepts and a description based on a status-quo analysis. 


\section{Ideological and Programme Discrepancies within the National Party}

The National Party, established in October 1928, struggled with numerous divisions and secessions, as well as inter-generation and personal conflicts. Ideological differences gave rise to several internal conflicts and regroupings. The National Party's views on the state's political system can hardly be considered coherent. Representatives of the "disobedient" generations, i.e. former members of the Popular National Union, were generally in favor of the principles of parliamentary democracy. However, diverse views and standpoints also appeared in the "professors"' group which included the supporters of liberalism and advocates of the totalization of political life. In addition, the "young" party members did not form an ideologically consistent group, representing various levels of political radicalism. Although in 1934 some of the more-radical young members left the National Party, it was still markedly divided. It might prove useful to quote the reflections by Julian Babiński, who distinguished three groups within the National Party, i.e. "the Poznań Orthodoxes", "the Warsaw Orthodoxes" and "the youth" (Babiński, 1937). In subsequent years, "the youth" divided into (1) Tadeusz Bielecki's group, and (2) Jędrzej Giertych and Kazimierz Kowalski's faction (Terej, 1979). Nevertheless, it is worth noting that, despite these discrepancies, the "youth" generation was generally in favor of more extreme forms of the state's political system, striving away from democratic or parliamentary solutions. In their statements, they referred to the issue of a mono-party, supporting the idea of "strong rule". Tendencies to overestimate the capacities of their own state also appeared in the views expressed by the young generation (Grott, 1996; Wapiński, 1997).

\section{The "Nation-state" System}

Views represented by the "youth" circles also differed. As stated by Roman Rybarski, one of the "professors"' group leaders, the nation-state system should be based on the nation's value, character, efforts and objectives. "Nationalism is not inherently related to any social or political doctrine. Nor does it arise from dictatorship, elitism, or the so-called totalism", he explained. Despite the existing ideological discrepancies, all the circles were convinced of the need to build a nation-state. The idea of the nation-state, viewed as the prerequisite, was also shared by all nationalistic ideologies (Rybarski, 1938).

The nation-state system was rudimentary to the National Party's political thought. As proven by the currently-available literature on the subject matter, the National Democrats, while placing the idea of a nation at the center, did not remain indifferent to state institutions. It is also worth noting that ideologists were absorbed by the thoughts on the political system from the early days of National Democracy's existence. Although in the views formulated during the partition period, a clear-cut vision of a political system could hardly be found, it was reflected in numerous statements regarding the nation or the future nation-state. 
Issues pertaining to the state's political system were considered in close connection with the overall philosophy of life. Declarations regarding the state's political system, based on unambiguous legal frameworks, were relatively frequent elements in the Party's programme. The need to build "a strong rule", frequently associated with the national élite, comprising individuals valuable and conscious in national terms, was often stressed. At the same time, statements made by the older generations sometimes reflected a certain mistrust of and distance from the emerging totalitarian systems.

In the years immediately preceding the May Coup d'État, a growing interest in the state's model which began to be implemented in Italy, after the Fascist faction led by Benito Mussolini, had come to power in 1922, could be noted in the National Democratic journalistic writing (Białokur, 2005). As written by K. Kawalec, (2000) the overall "atmosphere was increasingly conductive to the approval of extreme views". Roman Dmowski took a skeptical view on parliamentary work, and was inclined to search for new systemic and organizational forms ${ }^{2}$. Dmowski's opinion expressed at the meeting of the Camp of Great Poland in June 1931 could be considered symptomatic. "Frankly speaking, if I came to power, I would like to rule for two years without a parliament", he said (Kawalec, 2000). In 1934 Dmowski claimed that the idea of building a permanent political system had remained open (Dmowski, 1934). Diverse views were presented by Roman Rybarski who often argued with Dmowski in public. Rybarski was a politician aiming at preserving an independent position within the National Party and the Camp of Great Poland. He was, therefore, against the radical postulates made by Dmowski and his young supporters (Rybarski, 1936).

\section{From Parliamentary Ideas to the Authoritarian Rule Concept}

Along with the shifting "point of gravity" in the National Party's authorities towards the "youth" generation, parliamentary ideas were gradually replaced by the authoritarian rule concept. The latter was protested against by the older-generation activists who were slowly being marginalized. Among them was Prof.Wacław Komarnicki, a specialist in constitutional law, and the author of the draft constitution, who withdrew from active political life in 1935 for ideological and personal reasons. Komarnicki could not find common ground with the younger members, who eventually managed to dominate the National Party in the years immediately preceding the outbreak of World War II (Kilian, 2000). Komarnicki's recollections appear interesting from the cognitive point of view. Looking back at the situation in the National Party, he stated that the National Party activists had been too focused on the Jewish problem, which had clearly prevailed over the issues related to the state's political system, distorting the personal composition of the Party.

2 The Jagiellonian Library, Stanisław Rymar, Pamiętnik [Diary], vol. 2, file No. 9797 III, mf. P - 1344, W Polsce zjednoczonej, 1922-1939 [In the united Poland, 1922-1939], p. 170. 
Following the May Coup d'État, Stanisław Grabski also withdrew from active political life. He belonged neither to the Camp of Great Poland nor to the National Party, as his previous views, consistent with the liberal spirit and parliamentary methods, could not be accommodated within the National Party's ideological transitions. Grabski publicly stated that the National Party had abandoned its democratic ideas (Sobczak, 1998). In the National Party period, Grabski took his own standpoint on numerous issues, presenting his observations in various journalistic and scientific papers. He never abandoned the idea of disseminating his own views on the nation-state concept. In December 1934 Gazeta Warszawska [The Warsaw Gazette] strongly criticized Grabski, warning that his proposals might push the development of the nationalistic idea in the wrong direction. In response, Grabski made a clear statement in a book entitled Ku lepszej Polsce [Towards a better Poland], "faith in the national unity has substantially weakened. This has mainly been due to the fact that, following the Popular National Union's transition into the National Party, devoid of its democratic and socio-cultural elements, as well as its working for and with the people, on which the entire rural policy of the National Party had once been based, in line with Jan Ludwik Popławski's postulates, Fascist-like orders, briefings and gatherings eventually came to prevail" (Grabski, 1938).

In contrast, Joachim Bartoszewicz, who had been President of the General Board of the National Party from 1928, received Roman Dmowski's support. As a result, he was not ignored by the "youth" generation, (Maj, 2000; Białokur 2005), but his influence on the situation in the National Party was very limited. Notably, he was back then almost entirely blind, and this fact was undoubtedly significant. As Wojciech Wasiutyński wrote several years later, "despite his intelligence and merits, he should not have been made President of such a huge party, engaged in fierce political fights" (Wasiutyński, 1996). This was even more so, as "ruling from the backstage" - as Juliusz Zdanowski called it - had met with aversion among the National Party members. Scientific literature includes opinions that Dmowski at that time followed in Piłsudski's footsteps, considering that the latter, after the May Coup d'État, had promoted a figurehead to the chief position in the state. At this point, one can hardly ignore the fact that Roman Dmowski found himself in a deadlock situation, and this phenomenon was indeed much wider, as reflected by the changes occurring in the Party's management. Immediately after World War I, it was dominated by parliamentarians. Then, with the young members coming to power, many of them, including Prof. Stanisław Rymar and activists belonging to the so-called professors' group, opted for "internal emigration", formally retaining their member status, but actually cutting their ideological and political activities to the minimum (Kawalec, 2002).

The concepts developed by "the old members", and reflected in the National Party's programme of 1928, were aimed at modifying the system introduced by the March constitution, by significantly reducing the powers vested in law-making authorities (Rybarski, 1928). The proposed system solutions were consistent with the parliamentary system concept. The criticism of parliamentarism, though verbally strong, was not meant to entirely negate 
this political system. Most of older-generation activists viewed limited parliamentarism as a system within which the national élite would be offered unlimited opportunities to impact on, or participate in, political rule. Contrary to "the old members", the youth circles, also exhibiting ideological differences, eventually decided to criticize liberalism and negate the principles of parliamentary democracy. Such notions as the nation organization or the national élite were also interpreted in different ways than in the "disobedient generation" circles (Kawalec, 1989).

\section{Criticism of Democracy}

National Party members criticized both the order binding before the May Coup d'État and the system solutions introduced after 1926. As a result of the May events, the National Party became an opposition party. Due to the establishing of Centrolew (a center-left coalition), the national faction underwent political separation. The democratic system did not generate much enthusiasm among the National Party thinkers, especially among the young generation, supported by Roman Dmowski (1933). It was believed that democracy was against the principles of the nation-state. Democracy was viewed as based on, firstly, the $18^{\text {th }}$-Century philosophical ideas disseminated by Masonic lodges, and, secondly, French-Revolution slogans. Theoretical justifications for democracy were sought in Jean Jacques Rousseau's political philosophy while the origins and consolidation of democratic institutions dated back to the second half of the "unwise" $19^{\text {th }}$ Century. Members of the younger generation expressed critical views on democratic solutions and the parliamentary republic model. Journalist Zdzisław Stahl questioned both "the doctrinaire", and the "shallow democratic" order which was considered artificial and mechanical, (Stahl, 1928, 1929). It was believed that the idea of equality, as promoted by democracy, was unattainable (Frycz, 1936). In addition, the democratic system was seen as contradictory to the postulated principle of elitism, with the hierarchical social structure's constituting the prerequisite to the establishing of the national élite (Piestrzyński, 1928).

\section{Criticism of Totalitarianism}

Along with the criticism of democracy, critical remarks were also made in respect of totalitarianism. Wacław Komarnicki, (1937) representing the liberal faction of the National Party, ruled out the possibility of developing a totalitarian system in Poland, claiming that "There are absolutely no grounds which could warrant its success" (Komarnicki, 1937). Fears were also expressed that a totalitarian system, when introduced on an experimental basis, could pose a threat to the Polish State. Anti-democratic tendencies, however, did not meet with the approval of all National Party members. "I was against any totalitarian, and the so-called authoritarian, forms. I supported close cooperation with other opposition parties in Poland, and I was in favor of entering numerous social and professional organizations, 
even those totally different from ours"3, said Stanisław Rymar, President of the Kraków branch of the National Party, who was inclined to trust in democratic mechanisms. Rymar, supporting democratic forms and criticizing the activities of the pro-Piłsudski formation, wrote in March 1936 "we should pave our way to our society, and to true representatives of our society, in a different way. We need to organize new elections to all representative bodies. Unless we take such measures, there will be no change for the better!"4

The political system of the nation-state was expected to meet the needs of the nation, and be consistent with its unique spirit (Trella 1936). Any transposition of foreign (external) system-related patterns and solutions was considered exceptionally harmful. Wacław Komarnicki advocated that "the Constitution cannot be an artificial reflection of any abstract reasoning, but it must be based on collective life experience, and consider the unique characteristics of a nation. The implantation of any foreign patterns should only be allowed to a limited extent, but they should be adjusted to the life and features of the nation" (Komarnicki, 1930).

\section{The Polish Nation as a Sovereign}

The nation-state system was thoroughly considered by the National Party politicians. The objective was to build a national system which would serve the needs of the nation, based on national and Catholic values. The underlying principle of the national system was to put the Polish nation in the position of sole sovereignty, capable of taking autonomous decisions. The National Party adopted the principle that the source of power was attributed to the Polish nation (Winiarski, 1935). Accounts of the National Party's political thought unambiguously indicate that the nation should be sovereign. The revised draft Constitution, which was presented by the National Club in March 1929, contained a statement that the Polish nation constituted the only source of any state authority in the Republic of Poland. The political system was mainly expected to protect the national interests. Perceiving the Polish nation as the sovereignty, the National Party leaders believed that it was the sovereign which should decide about the directions of both the internal and external policies of the country. The political system should also correspond to the character of the Polish nation, and also to its unique values, efforts and principles. Aiming at defining sovereignty, the National Party journalists seemed to have no doubts about "the nation's being the source of power" (Wasiutyński, 1936). The Party was in favor of building not only a strong political authority but also a robust system, which, according to its members, should correspond to the needs and unique character of the nation.

3 The Jagiellonian Library, Stanisław Rymar, Pamiętnik [Diary], Part 2, rkp., File No. 9797/III, p. 154.

4 The New Files Archives, Stanisław Rymar's Files, File No. 6, Supplemented recollections of the period between 1919 and 1939. Fragments of articles and speeches by S. Rymar, p. 212. 
The idea, which was inspired by Catholic thought, and in particular by the views expressed by Saint Thomas Aquinas, was for the state to abandon all its creativity in the ideological domain, which was typical, inter alia, of some totalitarian systems in interwar Europe. This line of reasoning encouraged the view that the state should allow the Church to exert a substantial impact on individuals, as the condition necessary for infiltrating the Christian philosophy of life. This was later evidenced by the development of the political thought represented by the "youth" faction of the National Party, and by the fact that families and other social relationships were given much independence by the state authorities, which was also consistent with the teachings of Saint Thomas. Power was considered the attribute of God (Stahl, 1931).

\section{"Monarchy, Republic or Dictatorship?"}

The postulated form of the state's political system was clearly consistent with the above interests, which were markedly present in the National Party's political thought. Deliberations on the desirable form of political system were inspired by the sense of the weakness of state power, the disappointing democratic order, and the attempts made by the pro-Piłsudski formation at establishing an authoritarian state model. References were made to monarchical thought, with the "monarchy, republic or dictatorship" question constituting a main element in the political system considerations (Dmowski, 1939; Maj, 2001).

Monarchy, being one of the oldest political forms, was of much interest to representatives of various ideological movements. The sense of a parliamentary crisis, or even anachronism, provided an incentive to discuss the prospects of re-introducing monarchy. The intensifying democratic and parliamentary crisis coincided with the proliferation of monarchist organization and circles (Mackiewicz, 1927; Górski, 1999; Jaruzelski, 1987; Gzela 2009). Intensified activities by the politicians who had previously expressed criticism of the parliamentary and democratic order were outcomes of the May Coup d'État. Although monarchy-related considerations could hardly be viewed as some of the leading problems being dealt with by national ideologists, deliberations on monarchism and the institution of the monarchy were present among representatives of both the older and younger generations of the National Party members (Meller, 2011).

Favorable opinions on the monarchical system were formulated especially by representatives of the younger generation, whose ideology drew much inspiration from the conservative doctrine (Mich, 2001; Gzella, 1993). Representatives of "the old" circles also expressed keen interest in the monarchy, with Stefan Dąbrowski's being an appropriate example. He was actively involved in organizing a group aiming at the restoration of the monarchy, referred to as the Union of Polish Monarchists (Malinowski, 2014).

The monarchical system was perceived from both the historical and symbolic perspectives. It was viewed as being consistent with the Latin civilization traditions and the hierarchical ideas postulated by the youth. Monarchy was also seen as (1) a guarantee of 
a strong political power; (2) a symbol of the state's equilibrium; and (3) common ground for cooperation and arbitration involving various political parties. It was believed that the postulate of the hierarchization of the political and social domain, frequently repeated by the younger generation, was in line with the monarchical principle. As stated by Wojciech Wasiutyński, a representative of the "youth" circle, "Attempts at achieving a hierarchical ordering of life constitute the most-distinctive feature of the young Polish generation - in which a voluntarily adopted hierarchy of a political organization of the nation is being introduced, and attempts are being made at developing a hierarchy of objectives, which is being equally strongly reflected in (...) the pious attitude of the young generation" (Wasiutyński, 1933).

The notion of political system hierarchization, frequently appearing in documents referring to political thought, also merits additional clarification. In a system based on hierarchical principles, the position of a person was determined by his/her contribution to, and involvement in, the development of the national community. The inclination of the younger generation towards an apologia for monarchy was further developed in the ideology of radical groups, including ONR-ABC and RNR - Falanga. Statements made by Jan Korolec, a journalist and member of ONR-ABC, who viewed monarchy as the most appropriate political system for Poland, consistent with Polish traditions, provide an accurate example (Korolec, 1935, 1936).

Based on the political experience of the First Republic of Poland, deliberations on the desirable political form of the state led to the conclusion that a hereditary monarchy was the most appropriate form of monarchy. It was expected to make political power stable by granting sufficient prestige, respect and independence to the monarch, while preserving the extremely important and desirable continuity of political authority, as well as eliminating any competition between political parties, and, thus, preventing the state from falling into chaos. Monarchy was viewed as the synonym of the desirable continuity of political power. The authority handed down from generation to generation was treated as a precious element in the political system, whereas elective monarchy raised serious objections.

As regards the views on monarchism expressed by National Party journalists, ideologists and politicians, the natural succession of power constituted an important issue. Statements made by the young generation frequently contained approval of the inheritance of power. It was believed that the perpetual power vested in the monarch and, in the long run, also in the dynasty ruling the country, would be beneficial to the development of both the nation and the country. Representatives of the "youth" circles, treating monarchy as a desirable form of the state's political system, claimed that it would warrant (1) the appropriate prestige; (2) respect and independence of political power; (3) the continuity of power, (4) the avoidance of lawlessness, chaos and anarchy in the country; (5) reasonable cooperation between political parties; (6) the elimination of the national minorities' impact on the country's internal affairs; and (7) the internal and external security of the country. However, they did not present themselves as uncritical supporters of the monarchical system. Along with 
voices of approval, critical opinions on monarchy could also be heard. Far less sympathy for the monarchical system was expressed, inter alia, by Karol Stojanowski, who claimed that it would collide with the nation-state vision promoted by the National Party. According to Stojanowski, the re-introduction of the monarchy could strengthen the position of national minorities in the country (Stojanowski, 1936).

The monarchy-related deliberations led to very-cautious opinions on seeing the monarchical plans through. Discussions on the monarchical system were, to a large extent, purely theoretical, as it was believed that Poland lacked both the political and social premises to adopt this solution. Those who approached the idea of monarchy restitution with skepticism pointed to the non-existence of any royal dynasty in Poland and the major difficulties to be encountered with its establishing. According to National Democracy journalists, this was a serious factor hindering the restitution of the monarchy. Issues regarding the candidate to the throne, and the potential dynasty founder, were widely discussed. An elective monarchy system was strongly rejected in view of the previous Polish experience, which had proven that this form of governance was not beneficial to the country. Supporters of the monarchy restitution idea were aware of the non-existence of any historical dynasty, and the lack of any legitimate points for any specific family to be put forward as a candidate for establishing a royal dynasty in Poland. Finding the right person, capable of initiating a dynastic family, seemed an extremely challenging task, especially in view of the fact that, as claimed by young journalist Karol Stefan Frycz, the advocate of the monarchist system and supporter of the monarchy restitution idea, "the first King must always be someone special, and someone special is sometimes hard to find" (Frycz, 1937). According to Frycz, the founder of a new dynasty should be sought among representatives of the outstanding historical noble families, representing both Polish and European aristocracy, including in particular the Czartoryski and Zamoyski families. The journalist also considered the idea of the dynasty's being started by a descendant of the Bonaparte family5.

Based on the analysis of the accounts of the National Party's political thought, it can be inferred that the possibility of the restitution of the monarchical form of government in the Republic of Poland was not entirely ruled out. Several texts written by various ideologists and publicists clearly revealed an interest in the monarchy. Similar interest was also displayed by representatives of the older generation.

Roman Dmowski, rather than expressing a keen interest in the monarchy's restitution, willingly commented on the postulates being expressed by the monarchical movement, exposing the weaknesses of the Polish monarchical idea. "The sense of an improper government system has recently given rise to the formation of a rather vociferous monarchist idea. However, the manifestation methods employed by this movement seem to reflect its shallow nature, and the limited political awareness of its followers. They do not usually address the

5 The Jagiellonian Library, Karol Stefan Frycz, Prawdziwa Polska [The true Poland], b. m. w., rkps., File No. 120/97, p. 87. 
question of what the political system and the relationship between various authorities in their monarchy should be, and, even if they do, their response tends to take us back to at least the $18^{\text {th }}$ Century. Actually, no monarchical programme has been developed to date, and what we hear is the monarchical platitude. The issue of the legislative power, and its relationship with executive power, as well as the rights and attributes vested in the head of state, appear much more important than the question of whether Poland should be a republic or a monarchy", he wrote (Dmowski, 1939).

Some representatives of the National Party perceived the monarchy as (1) a guarantee of strong political power; (2) a symbol of the state's equilibrium; and (3) common ground for cooperation and arbitration involving various political parties. Opinions were expressed that the monarchical system would eliminate the influence of representatives of the Communist movement on the state authority. Although some Party leaders saw a possibility of the restitution of the monarchical form of government in the Republic of Poland, critical opinions regarding this issue were prevalent, with the lack of monarchist traditions being put forward as an irrefutable argument.

Deliberations on executive bodies also inspired reflection on the power vested in one person. Critical views on individual dictatorship were expressed by representatives of both the older and younger generations (Bartoszewicz, 1935). An opinion regarding the very limited usefulness of dictatorship for the Polish nation was generally shared within National Democracy circles.

\section{Concluding Remarks}

Based on an analysis of the National Party's political thought, several conclusions can be formulated. The National Party developed its own views regarding political systems. These were, to a large extent, determined by their own system of values based on the national idea. The National Party's political system projections were mainly inspired by (1) the successes of the "new type" states; (2) pressure from totalitarian systems; and (3) the influence of the economic and spiritual crisis. The National Party leaders wanted to make the political system more efficient. Nonetheless, views in favour of directly imitating any foreign political systems could hardly be found in the Party's political thought. The National Party's ideologists and journalists invariably stated that there was no pre-defined political system, but its form had to be adjusted to the specificity and unique character of a given national body (Nowosad, 1938; Wasiutyński, 1935). Although inspiration was drawn from external political systems, the Party's political thought did not lose its independence.

The National Party's political thought displayed a significant degree of complexity. It can be noted that, as regards individual opinions and views, it was far from uniform. No clear-cut political system proposal was developed, with the National Party's undergoing profound ideological and organizational changes. The Party was subject to major ideological evolution and internal divisions, which made its political thought much more complex. The system 
solutions suggested by the "disobedient" circles were generally consistent with the liberal state model. In contrast, the "youth" group, by contesting the idea of a liberal democracy, sought to make the political system based on the following principles: (1) the state authority; (2) the continuity of power; (3) hierarchization; and (4) discipline. These internal differences hindered the development of a new and up-to-date political programme. For the entire period of the National Party's operation during the Second Republic of Poland, i.e. between 1928 and 1939, only one programme, adopted in 1928, was formally in force. Its provisions, however, were strongly opposed an enormous number of the National Party's ideologists in subsequent years. Despite the visible differences and ideological discrepancies, one can note that the values based on the Christian philosophy of life were close to both supporters of the parliamentary order and representatives of the more radical younger generation. The significance of moral and Catholic values was invariably emphasized, being seen as the basis for the projected political order.

\section{References}

Babiński J. (1937). Geografia polityczna w Polsce A.D. 1937 [Political geography in Poland A.D. 1937]. Warsaw.

Białokur, M. (2005). Myśl społeczno-polityczna Joachima Bartoszewicza [Joachim Bartoszewicz's socio-political thought]. Torun.

Bartoszewicz, J. (1923). Podręczny słownik polityczny [A political dictionary], Warsaw.

Białokur, M. (2005). Myśl społeczno-polityczna Joachima Bartoszewicza [Joachim Bartoszewicz's socio-political thought]. Torun.

Dawidowicz A. (2017). Stronnictwo Narodowe 1928-1939. Wspólnota ideatu czy alternacja koncepcji [An ideal community or a concept alternati]. Lublin.

Dmowski, R. (1933). Ludzie potrzebni [The needed people]. Myśl Narodowa, No. 54, p. 813.

Dmowski, R. (1934). Konstytucja, Sejm a życie [The Constitution, the Sejm vs. life]. Gazeta Warszawska, February 2, 1934, p. 2.

Dmowski, R. (1939). Pisma, tom X, Od Obozu Wielkiej Polski do Stronnictwa Narodowego [Letters, Volume X. From the Camp of Great Poland to the National Party]. Częstochowa.

Frycz, K.S. (1936). O etosie i etnosie [About ethos and ethnos], Myśl Narodowa [National thought], No. 15, pp. 225-227.

Frycz, K.S. (1937). Na widowni [In the audience], Myśl Narodowa [National thought], No. 35, p. 549.

Górski, A. (1999). Władza polityczna w myśli Stanistawa Cata-Mackiewicza [Political power as viewed by Stanisław Cat-Mackiewicz], Kraków.

Grabski, S. (1938). Ku lepszej Polsce [Towards a better Poland]. Warsaw.

Grott, B. (1996). Adam Doboszyński o ustroju Polski [Adam Doboszyński - About the political system in Poland]. Warsaw.

Grott, B. (2014). Dylematy polskiego nacjonalizmu. Powrót do tradycji czy przebudowa narodowego ducha [The dilemmas of Polish nationalism. Return to tradition or reconstruction of the national spirit?]. Warsaw.

Gzella, J. (1987). „Stowo” - pismo konserwatystów wileńskich 1922-1939 [“The Word” - the Vilnius 
conservatist paper 1922-1939]. In W. Mich, B. Borowik, (ed.) Z dziejów prasy konserwatywnej. Przegląd tytułów [The history of conservative press. A review of titles], Lublin, pp. 141-161.

Gzella, J.(1993). Myśl polityczna Władysława Studnickiego na tle koncepcji konserwatystów polskich [Władysław Studnicki's political thought presented against the Polish conservatist concepts]. Toruń.

Jaruzelski, J.(1987). Stanisław Cat-Mackiewicz, 1896-1999, Wilno - Londyn - Warszawa [Stanisław Cat-Mackiewicz, 1896-1999, Vilnius - London - Warsaw]. Warsaw.

Kawalec, K. (2000). Spadkobiercy niepokornych. Dzieje polskiej myśli politycznej 1918-1939 [Inheritors of the disobedient. The history of Polish political thought 1918-1939]. Wrocław.

Kawalec, K. (2002). Zygmunt Wasilewski o narodzie, cywilizacji zachodniej i dobie powojennej [Zygmunt Wasilewski about the nation, western civilisation and post-war times], In: M. Meducka, (ed.) Zygmunt Wasilewski. Polityk - krytyk - regionalista [Zygmunt Wasilewski. Politician critic - regionalist]. Kielce, (pp. 25-26).

Kawalec, K. (1989). Narodowa Demokracja wobec faszyzmu 1922-1939. Ze studiów nad dziejami myśli politycznej obozu narodowego [National Democracy vs. fascism 1922-1939. Studies on the history of the National Party's political thought]. Warsaw.

Kilian, S. (2000). Wacław Komarnicki o ustroju państwa i konstytucji [Wacław Komarnicki on the state's political system and constitution]. Warsaw, p. 11.

Klub Narodowy o projekcie konstytucji. Przemówienia senatorów Klubu Narodowego wygłoszone dn. 15 stycznia 1935 roku podczas rozprawy nad projektem nowej konstytucji: przemówienie senatora Joachima Bartoszewicza [The National Club on the draft constitution. Speeches given by Senators of the National Club on 15 January 1935 during the discussion on the new draft constitution: Joachin Bartoszewicz's speech]. (1935). „Gazeta Warszawska” [The Warsaw Paper], 21 January 1935, No. 24, p. 6.

Komarnicki, W. (1930). O konstytucję narodowa. Stanowisko Stronnictwa Narodowego w sprawie rewizji konstytucji oraz tekst projektu rewizji złożonego przez Klub Narodowy w Komisji Konstytucyjnej Sejmu [The national constitution. The National Party's standpoint on the constitution's revision and the revised draft text submitted to the Constitution Commission of the Sejm by the National Club]. Warsaw.

Komarnicki, W. (1937). Totalizm a Polska [Totalism and Poland]. Myśl Narodowa. [National thought], No. 49 , p. 752.

Korolec, J. (1935). Odpowiedź megalomana [A megalomaniac response]. Prosto z Mostu [Point-blank], No. 43, p. 7.

Korolec, J. (1936). Ustrój polityczny nowej Polski [A political system of the new Poland]. Nowy Ład [The new order], No. 1, p. 4.

Mackiewicz, S. (1927). Kropka nad i [Dot the i's and cross the t's]. Warsaw.

Maj, E. (2000). Związek Ludowo-Narodowy 1919-1928. Studium z dziejów myśli politycznej [The Popular National Union 1919-1928. A study of the history of political though]. Lublin.

Malinowski, J. (2014). Stefan Dąbrowski (1877-1947). Biografia polityczna [Stefan Dąbrowski (1877-1947). A political biography]. Poznań.

Meller, A. (2011). Wątki monarchistyczne w publicystyce obozu narodowego 1918-1939 [Monarchistic traits in the National Party's journalistic writing], In A. Lewandowski, A. Meller, W. Wojdyło, (eds) Ustrój państwa w polskiej myśli politycznej XX-XXI wieku [The political system in Polish political thought in the $20^{\text {th }} / 21^{\text {st }}$ centuries]. Toruń, pp. 67-99. 
Mich, W. (2001). Polscy konserwatyści [Polish Conservatists], In J. Jachymek, W. Paruch, (eds), Więcej niż niepodległość. Polska myśl polityczna 1918-1939 [More than independence. Polish political thought in 1918-1939]. Lublin.

Nowosad, W. (1938). W walce o katolickie państwo polskiego narodu [Fighting for the Catholic state of the Polish nation]. Lviv.

Piestrzyński, R. (1928). O zorganizowanie elity narodowej [About organising the national élite]. Awangarda, No. 2, p. 5.

Rybarski R. (1933). Przyszłość gospodarcza Polski [Poland's economic future]. Warsaw.

Rybarski, R. (1928). Naprawa konstytucji [Repairing the constitution]. Myśl Narodowa [National thought], 17 February 1928, No. 6, pp. 61-62.

Rybarski, R. (1936). Siła i prawo [Power and law]. Warsaw.

Rybarski, R. (1938). Odmiany nacjonalizmu [The types of nationalism]. Myśl Narodowa [National thought], No. 47, p. 718.

Sobczak, M. (1988). Stosunek Narodowej demokracji do kwestii żydowskiej w Polsce w latach 1918-1939 [National Democracy's attitude to the Jewish issue in Poland in 1918-1939]. Wrocław.

Stahl, Z. (1928). O pojmowaniu polityki [About interpreting politics]. Myśl Narodowa [National thought], No. 27, pp. 444-445.

Stahl, Z. (1929). Odebrać ludności - oddać narodowi [Take away from people - give back to the nation]. Awangarda, No. 4, p. 70.

Stahl, Z. (1931). O podmiocie władzy państwowej [On the subject of state authority]. Myśl Narodowa [National thought], No. 48, p. 217.

Stojanowski, K. (1936). Monarchia czy państwo narodowe? [A monarchy or a nation-state?], „Myśl Narodowa" [National thought], No. 13, p. 259.

Szczutowski, S. (1935). Fale dziejowe [Waves of history]. Prosto z Mostu [Point-blank], No. 46, p. 1.

Terej, J.J. (1979). Rzeczywistość i polityka. Ze studiów nad dziejami najnowszymi Narodowej Demokracji [Reality vs. politics. Studies on the latest history of National Democracy]. Warsaw.

The Jagiellonian Library, Karol Stefan Frycz, Prawdziwa Polska [The true Poland], b. m. w., rkps., File No. $120 / 97$, p. 87.

The Jagiellonian Library, Stanisław Rymar, Pamiętnik [Diary], Part 2, rkp., File No. 9797/III, p. 154.

The Jagiellonian Library, Stanisław Rymar, Pamiętnik [Diary], Vol. 2, file No. 9797 III, mf. P - 1344, W Polsce zjednoczonej, 1922-1939 [In the united Poland, 1922-1939], p. 170.

The New Files Archives, Stanisław Rymar's Files, File No. 6, Supplemented recollections of the period between 1919 and 1939. Fragments of articles and speeches by S. Rymar, p. 212.

Trella, L. (1936). Państwo dobrem narodu [The state as the nation's welfare]. Wielka Polska [Great Poland], No. 13, p. 2.

Wapiński, R. (1988). Problem państwa w koncepcjach politycznych obozu narodowego [The issue of the state in the political concepts of the national party]. In W. Wrzesiński, (ed.) Polska myśl polityczna XIX i XX wieku [Polish political thought in the $19^{\text {th }}$ and $20^{\text {th }}$ centuries], vol. 7: Państwo w polskiej myśli politycznej [The state in the Polish political thought]. Wrocław, pp. 83-104.

Wapiński, R. (1997). Historia polskiej myśli politycznej XIX i XX wieku [The history of Polish political thought in the $19^{\text {th }}$ and $20^{\text {th }}$ centuries]. Gdańsk.

Wasiutyński, B. (1936). Siła i prawo [Power and law]. Myśl Narodowa [National thought], No. 18, p. 278. 
Wasiutyński, W. (1935). Naród rządzący [The ruling nation]. Warsaw.

Wasiutyński, W. (1933). W obronie przywileju [Defenfing the privilege]. Myśl Narodowa [National thought], No. 14, p. 178.

Wasiutyński, W. (1996). Prawa strona labiryntu, Fragmenty wspomnień [The right side of the labyrinth. Fragments of recollections], elaborated and edited by W. Turek, introductory remarks by W. Walendziak. Gdańsk.

Winiarski, B. (1935). My i oni w walce o konstytucje [We and them, fighting for the constitution]. Poznań.

\section{Author}

\section{Aneta Dawidowicz}

dawidowicz.aneta@gmail.com - professor at the Department of Political Science, Maria CurieSkłodowska University; contact details: Plac Litewski 3, Lublin. 